\title{
The Nexus of Tourism Spending with Economic Performance: A Panel Data Analysis for the Eurozone Area
}

\author{
Ageliki Anagnostou ${ }^{\mathrm{A}}$, George Ekonomou ${ }^{\mathrm{B}, \mathrm{C}}$, Dimitris Kallioras ${ }^{\mathrm{D} *}$ \\ Received: November 23, 2020 | Revised: January 24, 2021 | Accepted: January 25, 2021 \\ doi: 10.5937/gp25-29541
}

\begin{abstract}
The paper investigates the nexus of tourism spending (i.e. leisure and business tourism spending) with economic performance (i.e. GDP and employment) for the Eurozone countries, during the period 2000 2018, employing sophisticated panel data analysis techniques. The issue is salient, given that within the Eurozone economic space the abolition of border impediments has released dynamics and brought into surface a new mix of opportunities, threats and challenges that has been changing the balance between centripetal and centrifugal forces. The findings of the paper identify the long-run equilibrium and confirm the bi-directional relationships among the variables considered, thus contributing to the discussion on the relationship between tourism and economic performance.
\end{abstract}

Keywords: business tourism spending; leisure tourism spending; GDP; employment; panel data analysis; Eurozone area

\section{Introduction}

The tourism industry pursues paths to develop markets that are both promising, in terms of demand, and challenging, in terms of supply (Tsui et al., 2017; WTTC, 2019). Thus, tourism may create opportunities, especially concerning the gross domestic product (GDP) and employment, with positive externalities and multiplicative effects (Khan et al., 1995; Chao et al., 2006). In an era of globalization, and under volatile market conditions, such a perspective becomes of paramount importance. This is especially so within economic integration schemes.

Business and leisure tourism spending represent a couple of major, profitable, and popular market seg- ments within tourism industry (WTTC, 2019). Both segments may consider as natural developments of networking and alliances at the interface of open and integrated economies. Given the ever-increasing demand for travelling to international destinations, identified growth patterns in the tourism sector may, apparently, indicate the ever-growing competition among destinations (Lim \& Won, 2020). Hence, emphasis must be placed on identifying patterns that consider tourism spending not only as a mere macroeconomic variable but also - and most importantly - as a (or the) key factor that may generate positive externalities and multiplicative effects in the national economies.

\footnotetext{
A University of Thessaly, Department of Economics; aganag@uth.gr

B Agricultural University of Athens, Department of Management Economy and Communications of Cultural and Tourism Units; goikonomoug@aua.gr

C University of Thessaly, Department of Planning and Regional Development; goikonomou@uth.gr

D University of Thessaly, Department of Planning and Regional Development; Pedion Areos, PO 38334, Volos, Greece dkallior@uth.gr; https://orcid.org/0000-0003-3060-3745

* Corresponding Author: Dimitris Kallioras; e-mail: dkallior@uth.gr; phone: (+30)2421074484, fax: (+30)2421074385
} 
The paper investigates the nexus of business and leisure tourism spending with GDP and employment for the Eurozone area. To this end, the paper employs sophisticated panel data analysis techniques (i.e. unit root, cointegration, and causality analyses). The issue is salient given that within the EU economic space - and much more within the Eurozone economic space - the abolition of border impediments has released dynamics and brought into surface a new mix of opportunities, threats and challenges that has been changing the balance between centripetal and centrifugal forces (Kallioras et al., 2009 and 2017; Petrakos et al., 2011; Anagnostou et al., 2016). The findings of the paper identify the long-run equi- librium and confirm the bi-directional relationships among the variables considered, thus contributing to the discussion on the relationship between tourism and economic performance. The analysis covers the period 2000-2018 and utilizes data obtained from the World Travel \& Tourism Council (WTTC) and the World Bank. The findings of the paper offer clear-cut policy suggestions.

The remainder of the paper is as follows. Section 2 reviews the literature on the causal relationships between tourism and economic growth. Section 3 presents the data and deploys the methodology. Section 4 performs the empirical analysis and discusses the findings. Section 5 offers the conclusions.

\section{Theoretical Background}

The relationship between tourism and economic growth is defined (Oh, 2005; Tugcu, 2014) in terms of four related hypotheses. The "tourism-led economic growth" ("TLEG") hypothesis indicates a uni-directional causality between tourism expansion and economic growth, in the sense that the expansion of tourism strengthens economic growth. Thus, national governments may boost growth through subsidizing the tourism sector. In contrast, insufficient tourism policies or external shocks may hinder national economic growth prospects. The "economy-driven tourism growth" ("EDTG") or "reverse" hypothesis indicates a uni-directional causality running from economic growth to tourism expansion. Tourism plays an important - but not the primary - role in economic growth. Thus, national governments may, also, boost growth through subsidizing other sectors or leading industries. The "feedback" or "reciprocal" hypothesis indicates a bi-directional, reciprocal, causality between tourism expansion and economic growth. Tourism expansion affects economic growth, and vice versa. This means that tourism expansion policies may boost economic growth and higher economic growth may boost tourism expansion, in a selfsustained fashion. The "neutrality" hypothesis discloses the absence of any type of causality between tourism expansion and economic growth. Thus, tourism expansion is not a driver of economic growth and economic growth has no impact on tourism.

Against the backdrop of the four hypotheses that define the relationship between tourism and economic growth, the issue has been gaining increasing attention in the corresponding literature (Dwyer et al., 2004; Lee \& Chang, 2008; Pablo-Romero et al., 2013; de Vita \& Kyaw, 2016; inter alia). Yet, concerning the Eurozone countries only some sporadic studies, that mostly focus on the Mediterranean countries, exist. These studies, using a wide array of methodological approaches, covering different time periods, and utilizing different variables, provide, rather, inconsistent results. The "TLEG" hypothesis has been confirmed for Cyprus (Chou, 2013), for France (Tugcu, 2014; Demirhan, 2016), for Greece (Ivanov \& Webster, 2007; Soukiazis \& Proença, 2008; Eeckels et al., 2012), for Italy (Soukiazis \& Proença, 2008; Cortes-Jimenez \& Pulina, 2010; Tugcu, 2014; Demirhan, 2016), for Latvia (Chou, 2013), for Portugal (Soukiazis \& Proença, 2008; Neves et al., 2015; Cerdeira \& Bento, 2016; Demirhan, 2016), for Slovakia (Chou, 2013), and for Spain (Balaguer \& Cantavella-Jordá, 2002; Novak et al., 2007; Soukiazis \& Proença, 2008; Tugcu, 2014). Yet, the "TLEG" hypothesis has been rejected for Cyprus (Ivanov \& Webster, 2007), and for Spain (Ivanov \& Webster, 2007). The "EDTG" hypothesis has been confirmed for Cyprus (Katırcioğlu, 2009a), for Malta (Tugcu, 2014), for Slovakia (Škrinjarić, 2019), and for Slovenia (Tugcu, 2014; Gričar et al., 2016; Škrinjarić, 2019). The "feedback" hypothesis has been confirmed for Estonia (Chou, 2013), for France (Tugcu, 2014), for Greece (Dritsakis, 2004; Tugcu, 2014), for Italy (Massidda \& Mattana, 2013), for Malta (Katırcıoğlu, 2009b), and for Spain (Cortes-Jimenez \& Pulina, 2010). The "neutrality hypothesis" has been confirmed for Estonia (Chou, 2013), for Greece (Kasimati, 2011; Tugcu, 2014; Demirhan, 2016), for Malta (Tugcu, 2014), for Slovenia (Tugcu, 2014), and for Spain (Demirhan, 2016). Unstable and/or weak relations have been found for Austria, for Cyprus, for Germany, for Greece, for Italy, for the Netherlands, for Portugal, and for Spain (Dragouni et al., 2013; Antonakakis et al., 2015a \& 2015b).

There is, apparently, no concrete body of empirical literature on the relationship between tourism and economic growth for the Eurozone countries, and much more for the Eurozone area as a whole. The paper paves the road for a broad and comprehensive 
understanding on the issue through the treatment of the Eurozone area as a unified, integrated, area, through the decomposition of the tourism industry into the segments of business and leisure tourism, and through the study of economic performance both in terms of GDP and employment.

\section{Data}

The study compiles and utilizes a balanced panel dataset for the Eurozone countries, namely: Austria, Belgium, Cyprus, Estonia, Finland, France, Germany, Greece, Ireland, Italy, Latvia, Lithuania, Luxembourg, Malta, the Netherlands, Portugal, Slovakia, Slovenia, and Spain. Towards investigating the nexus of busi- ness and leisure tourism spending with GDP and employment, the paper employs the following variables: GDP ( $g d p)$, employment (empl), business tourism spending (bts), and leisure tourism spending (lts) (Table 1). The variables are expressed in logarithmic terms.

Table 1. Presentation of the variables

\begin{tabular}{|l|c|l|c|c|}
\hline Variable & Acronym & Definition & Measurement & Source \\
\hline GDP & $g d p$ & GDP & $€$ & World Bank \\
\hline employment & empl & employed people aged 15-67 & no. of employees & World Bank \\
\hline business tourism spending & $b t s$ & spending on business travel & $€$ & WTTC \\
\hline leisure tourism spending & lts & spending on leisure travel & $€$ & WTTC \\
\hline
\end{tabular}

Sources: WTTC / World Bank

\section{Methodology}

The paper investigates the nexus of business and leisure tourism spending with GDP and employment for the Eurozone countries, during the period 2000-2018. Towards examining the dynamic causal relationships between tourism spending variables and economic performance variables, the paper employs sophisticated, established, panel analysis techniques. Particularly, the empirical analysis is performed as follows: Initially, panel unit root tests for each series are undertaken, testing for the order of integration on the variables considered (i.e. $g d p$, empl, bts, and $l t s$ ). Then, having integration of order $1(I(1))$ in each series, panel cointegration tests are employed to investigate the existence of a long-run relationship between the sets of the variables considered. If the series of the variables considered are cointegrated, the long-run cointegration vector is estimated. Finally, if a long-run relationship between the sets of the variables considered is found to exist, and having estimated the corresponding long-run cointegration vectors, dynamic panel causality tests are applied to evaluate the corresponding short-run cointegration and the direction of the corresponding causality.

\section{Panel Unit Root Tests}

The first step of the empirical analysis is to conduct a series of panel unit root tests to determine the order of integration of the panel variables. Particularly, the paper employs five non-parametric unit root tests, name- ly: the LLC test (Levin et al., 2002), the Breitung test (Breitung, 2000), the IPS test (Im et al., 2003), the ADFFisher test (Maddala and Wu, 1999), and the PP-Fisher test (Choi, 2001). The first three tests assume a common unit root process across countries, while the other two assume individual unit root processes. All the aforementioned tests have the null hypothesis of unit roots.

\section{Panel Cointegration Tests}

Having established I(1) in the panel dataset, the second step of the empirical analysis is to determine whether long-run relationships exist. The paper employs the ADF-Fisher test (Maddala and $\mathrm{Wu}, 1999$ ). The latter is a Johansen Fisher-type test (Johansen, 1988) that combines tests from individual cross-sections to obtain a test statistic for the full panel. It is a non-parametric test that does not assume homogeneity in the coefficients. Having established that the series of the variables considered are cointegrated, the paper estimates the corresponding long-run cointegration vectors.

The long-run equilibrium relationship, given by the error correction terms (ECTs), is a measure of the extent by which the observed values in time $\mathrm{t}-1$ deviate from the long-run equilibrium relationship. Since the variables are cointegrated, any such deviation at time $\mathrm{t}-1$ should induce changes in the values of the variables in the next time point to force the variables back to the long-run equilibrium relationship. The following two equations are estimated: 


$$
\begin{aligned}
& \operatorname{lgdp}_{i t}\left(\text { lempl }_{i t}\right)=\alpha_{1, i}+\delta_{1, t}+\beta_{1, i} \text { lbts }_{i, t}\left(\text { llts }_{i, t}\right)+\eta_{i, t} \\
& \operatorname{lbts}_{i t}\left(\text { llts }_{i t}\right)=\alpha_{2, i}+\delta_{2, t}+\beta_{2, i} \operatorname{lgdp}_{i, t}\left(\operatorname{lempl}_{i, t}\right)+\phi_{i, t}
\end{aligned}
$$

where $i=1, \ldots, 19$ refers to each country in the panel dataset, $\mathrm{t}=2000, \ldots, 2018$ denotes each year considered, $\alpha_{1, i}$ and $\alpha_{2, i}$ are the country-specific fixed effects, $\delta_{1, t}$ and $\delta_{2, t}$ are the time-specific fixed effects, $\beta_{1, i}$ and $\beta_{2, i}$ ) are the coefficients, $\eta_{i, t}$ and $\phi_{i, t}$ are the disturbance terms, which follow the normal probability distribution with zero mean and constant variance, $\lg d p$, lempl, lbts, and llts are the natural logarithms of GDP, employment, business tourism spending, and leisure tourism spending, respectively. Since, all variables are expressed in natural logarithms, the estimated longrun coefficients may interpret as elasticities.

The long-run cointegration vector is estimated using the panel dynamic ordinary least squares (DOLS) estimation method (Mark \& Sul, 2003). The DOLS estimates are used in order to obtain the residuals as the ECTs. The DOLS estimator corrects standard ordinary least squares (OLS) estimator for bias induced by endogeneity and serial correlation on the leads and lags of the first-differenced regressors to control for potential endogeneities. Then, the OLS estimator is applied using the residuals from the first-step regression. Following Engle \& Yoo (1987), the Akaike information criterion (AIC) (Akaike, 1974) is used to determine the optimal specifications of equations (1) and (2).

\section{Panel Causality Tests}

The ADF-Fisher test (Maddala \& Wu, 1999) only indicates whether (or not) the variables are cointegrated and whether (or not) a long-run relationship exists between them. It does not indicate the direction of causality. Thus, having estimated equations (1) and (2) for each pair of the variables considered, and obtaining the estimated residuals $\left(\eta_{i, t}\right.$ and $\left.\phi_{i, t}\right)$, the paper proceeds in estimating the panel-based vector errorcorrection model (VECM) (Engle \& Granger, 1987) with the one-period lagged residuals (Holtz-Eakin et al., 1988). The panel-based VECM consists of the following two equations:

$$
\begin{aligned}
& \Delta l g d p_{i, t}\left(\Delta l e m p l_{i, t}\right)=\alpha_{1, i}+\sum_{k=1}^{h} \theta_{1,1, i, k} \Delta l g d p_{i, t-k}\left(\Delta l e m p l_{i, t-k}\right)+ \\
& \sum_{k=1}^{h} \theta_{1,2, i, k} \Delta l b t s_{i, t-k}\left(\Delta l l s_{i, t-k}\right)+\lambda_{1, i} \eta_{i, t}+u_{1, i, t}
\end{aligned}
$$

$$
\begin{aligned}
& \Delta l b t s_{i, t}\left(\Delta l l t s_{i, t}\right)=\alpha_{2, i}+\sum_{k=1}^{h} \theta_{2,1, i, k} \Delta l b t s_{i, t-k}\left(\Delta l l t s_{i, t-k}\right)+ \\
& \sum_{k=1}^{h} \theta_{2,2, i, k} \Delta l g d p_{i, t-k}\left(\Delta l e m p l_{i, t-k}\right)+\lambda_{2, i} \varphi_{i, t}+u_{2, i, t}
\end{aligned}
$$

where lgdp, lempl, lbts, and llts are the natural logarithms of GDP, employment, business tourism spending, and leisure tourism spending, respectively, $\Delta$ is the difference operator, $\eta_{i, t}$ and $\phi_{i, t}$ are the lagged residuals derived from the long-run cointegrating relationships in equations (1) and (2), $\theta_{1,1, i, k}$ ), $\theta_{1,2}, i, k, \theta_{2,1}, i, k$, and $\theta_{2,2, i, k}$ are the short-run adjustment coefficients, $\lambda_{1, i}$ and $\lambda_{2, i}$ measure how fast the values of the variables of the system come back to the long-run equilibrium levels when they deviate from them, $\mathrm{k}$ denotes lag length, $u_{1, i, t}$ and $u_{2, i, t}$ are the disturbance terms assumed to be uncorrelated with mean zero.

By using the variables in their differenced form, the paper takes care of the OLS estimation problem, which is due to the correlation between country-specific effects and explanatory variables. Nevertheless, differencing introduces the problem of simultaneity because the lagged dependent variables are correlated with the differenced ECTs. Furthermore, heteroscedasticity in the errors across the cross-section members is expected to occur. Hence, the application of an instrumental variable estimator, to cope with these problems, is necessary. A widely-used estimator is the panel GMM estimator (Arellano \& Bond, 1991). In the system of equations (3) and (4), pre-determined lags of the system variables are used as instruments to obtain consistent results. Following, again, Engle \& Yoo (1987), the paper uses the AIC (Akaike, 1974) to determine the optimal specifications of equations (3) and (4).

The source of causation can be identified by testing the significance of the coefficients of the independent variables, $\Delta l g d p_{i, t-k}\left(\Delta l e m p l_{i, t-k}\right)$ and $\Delta l b t s_{i, t-k}\left(\Delta l l t s_{i, t-k}\right)$, in equations (3) and (4). Checking for short-run causality, the null hypothesis is tested to detect whether short-run causality runs from $\Delta l g d p_{i, t-k}\left(\Delta l e m p l_{i, t-}\right.$ $\left.{ }_{k}\right)\left(H_{0}: \theta_{1,2, i, k}=0, \forall_{i, k}\right)$ and/or from $\Delta l b t s_{i, t-k}\left(\Delta l l t s_{i, t-k}\right)$ $\left.\left(H_{0}: \theta_{2,2, i, k}\right)=0, \forall_{i, k}\right)$. Checking for long-run causality, the significance of the speed of adjustment is tested (whether $\lambda_{1, i}=0$ and $\lambda_{2, i}=0$ ). Checking for strong causality, joint tests are applied by including the coefficients of the explanatory variables and the respective ECT of each equation. This specific notion of causality denotes which variables bear the burden of a shortrun adjustment to re-establish a long-run equilibrium, following a shock to the system (Asafu-Adjaye, 2000; Oh \& Lee, 2004a \& 2004b). Since all variables are represented in a stationary form, standard Wald F-tests (Wald, 1945) can be used when testing the various null hypotheses. 


\section{Results}

\section{Panel Unit Root Tests' Results}

The empirical analysis begins with conducting the LLC test (Levin et al., 2002), the Breitung test (Breitung, 2000), the IPS test (Im et al., 2003), the ADFFisher test (Maddala \& Wu, 1999), and the PP-Fisher test (Choi, 2001). As it can be inferred from the tests' statistics (Tables $2 \mathrm{~A}$ and $2 \mathrm{~B}$ ), the unit root hypothesis cannot be rejected. Particularly, in almost all cases, three out of the five or four out of the five unit root tests conducted report evidence of unit roots. Thus, from the unit roots tests, it can be concluded that the variables considered are $I(1)$. This indicates a possible long-run cointegrating relation.

\section{Panel Cointegration Tests' Results}

Having established for the different sets of variables, the existence of long-term relationships is examined by employing the ADF-Fisher test (Maddala \& Wu, 1999). The results show (Table 3 ) that the trace statistic and the maximum eigenvalue statistic of the null hy- pothesis are statistically significant for all sets of variables. This means that the null hypothesis is rejected, at the $5 \%$ significance level, indicating that there is a cointegration relationship between the pairs of the variables considered. Indeed, the empirical realizations of the trace statistic and the maximum eigenvalue statistic provide evidence in favor of a long-run relationship.

The long-run cointegrating relationships in equations (1) and (2) are estimated using the DOLS estimator (Mark \& Sul, 2003) to correct standard OLS for the bias induced by endogeneity and serial correlation. The long-run elasticity estimation results (Tables $4 \mathrm{~A}$ and $4 \mathrm{~B}$ ) indicate that the coefficients of both expenditure proxies are positive and statistically significant at the $5 \%$ level for all dependent variables. Specifically, both and affect and in a positive way. Particularly, an increase in by $1 \%$ increases and by $0.724 \%$ and $0.075 \%$, respectively, while an increase in by $1 \%$ increases and by $0.767 \%$ and $0.082 \%$ respectively. Also,

Table 2A. Panel unit root test results (levels)

\begin{tabular}{|c|l|c|c|c|c|c|}
\hline \multicolumn{2}{|c|}{ Variable } & LLC Test & Breitung Test & IPS Test & ADF-Fisher Test & PP-test Test \\
\hline \multirow{3}{*}{ lgdp } & Statistic & -2.48 & 1.48 & 1.73 & 21.42 & 19.08 \\
\cline { 2 - 7 } & Prob. & $0.01^{* *}$ & 0.93 & 0.96 & 0.99 & 1.00 \\
\hline \multirow{3}{*}{ lempl } & Statistic & -0.52 & 3.06 & 1.29 & 22.05 & 31.63 \\
\cline { 2 - 7 } & Prob. & 0.30 & 1.00 & 0.90 & 0.98 & 0.76 \\
\hline \multirow{2}{*}{ bts } & Statistic & -0.71 & 1.51 & 1.01 & 29.78 & 50.48 \\
\cline { 2 - 7 } & Prob. & 0.24 & 0.93 & 0.84 & 0.83 & 0.08 \\
\hline \multirow{2}{*}{ llts } & Statistic & -2.00 & 3.66 & 1.40 & 32.16 & 45.44 \\
\cline { 2 - 7 } & Prob. & $0.02^{* *}$ & 1.00 & 0.92 & 0.74 & 0.19 \\
\hline
\end{tabular}

** indicates statistical significance at the 5\% level.

Source: Authors' elaboration

Table 2B. Panel unit root test results (1st differences)

\begin{tabular}{|c|l|c|c|c|c|c|}
\hline \multicolumn{9}{|c|}{ Variable } & LLC Test & Breitung Test & IPS Test & ADF-Fisher Test & Fisher-type Test \\
\hline \multirow{3}{*}{ lgdp } & Statistic & -6.13 & -4.60 & -1.67 & 57.06 & 83.65 \\
\cline { 2 - 7 } & Prob. & $0.00^{* *}$ & $0.00^{* *}$ & $0.05^{* *}$ & $0.02^{* *}$ & $0.00^{* *}$ \\
\hline \multirow{3}{*}{ lempl } & Statistic & -4.77 & -3.14 & -1.54 & 55.28 & 83.31 \\
\cline { 2 - 7 } & Prob. & $0.00^{* *}$ & $0.00^{* *}$ & 0.06 & $0.03^{* *}$ & $0.00^{* *}$ \\
\hline \multirow{3}{*}{ lbts } & Statistic & -11.27 & -8.62 & -7.35 & 115.12 & 147.45 \\
\cline { 2 - 7 } & Prob. & $0.00^{* *}$ & $0.00^{* *}$ & $0.00^{* *}$ & $0.00^{* *}$ & $0.00 * *$ \\
\hline \multirow{2}{*}{ llts } & Statistic & -11.16 & -8.17 & -6.45 & 108.24 & 173.89 \\
\cline { 2 - 7 } & Prob. & $0.00^{* *}$ & $0.00^{* *}$ & $0.00^{* *}$ & $0.00^{* *}$ & $0.00 * *$ \\
\hline
\end{tabular}

** indicates statistical significance at the $5 \%$ level.

Source: Authors' elaboration 
Table 3. ADF-Fisher panel cointegration test results

\begin{tabular}{|l|l|c|c|c|c|}
\hline \multicolumn{2}{|l|}{ Variables } & $\begin{array}{c}\text { Fisher statistics } \\
\text { (from trace test) }\end{array}$ & P-value & $\begin{array}{c}\text { Fisher statistics (from } \\
\text { maximum eigenvalue test) }\end{array}$ & P-value \\
\hline \multirow{2}{*}{ lgdp E lbts } & none & $207.4^{* *}$ & 0.00 & $188.3^{* *}$ & 0.00 \\
\cline { 2 - 6 } & at most 1 & 84.08 & 0.00 & 84.08 & 0.00 \\
\hline \multirow{2}{*}{ Igdp \& llts } & none & $109.7^{* *}$ & 0.00 & $99.27^{* *}$ & 0.00 \\
\cline { 2 - 6 } & at most 1 & 60.51 & 0.01 & 60.51 & 0.01 \\
\hline \multirow{2}{*}{ lempl E lbts } & none & $142.3^{* *}$ & 0.00 & $127.5^{* *}$ & 0.00 \\
\cline { 2 - 6 } & at most 1 & 70.22 & 0.00 & 70.22 & 0.00 \\
\hline \multirow{2}{*}{ lempl E llts } & none & $101.9^{* *}$ & 0.00 & $84.05^{* *}$ & 0.00 \\
\cline { 2 - 6 } & at most 1 & 71.11 & 0.00 & 71.11 & 0.00 \\
\hline
\end{tabular}

** indicates rejection of the null hypothesis of no cointegration at least at the 5\% level of statistical significance. For each data set, in each panel, the null hypothesis () is tested using the observed trace statistic and maximum eigenvalue statistic. If the null hypothesis is rejected, the alternative hypothesis () is examined.

Source: Authors' elaboration

Table 4A. Long-run elasticity estimation results (estimations of equation 1)

\begin{tabular}{|c|c|c|c|c|}
\hline Independent Variables & \multicolumn{2}{|c|}{$l g d p$} & \multicolumn{2}{c|}{ lempl } \\
\hline Dependent Variables & estimates & t-stat & estimates & t-stat \\
\hline lbts & 0.724 & $11.250^{* *}$ & 0.075 & $2.604^{* *}$ \\
\hline llts & 0.767 & $15.418^{* *}$ & 0.082 & $3.239^{* *}$ \\
\hline
\end{tabular}

** denotes statistical significance at the $5 \%$ level.

Source: Authors' elaboration

Table 4B. Long-run elasticity estimation results (estimations of equation 2)

\begin{tabular}{|c|c|c|c|c|}
\hline Independent Variables & lbts & & llts & \\
\hline Dependent Variables & estimates & t-stat & estimates & t-stat \\
\hline lgdp & 0.909 & $12.905^{* *}$ & 0.977 & $17.195^{* *}$ \\
\hline lempl & 0.892 & $2.186^{* *}$ & 0.826 & $1.780^{*}$ \\
\hline
\end{tabular}

** and * denote statistical significance at the 5\% and 10\% level, respectively.

Source: Authors' elaboration

both and affect and in a positive way. Particularly, an increase in by $1 \%$ increases and by $0.909 \%$ and $0.977 \%$, respectively, while an increase in by $1 \%$ increases and by $0.892 \%$ and $0.826 \%$, respectively.

\section{Panel Causality Tests' Results}

The long-run causal relationships between the pairs of the variables considered is examined with the use of panel VECM. Defining the lagged residuals (, ) from the estimated long-run cointegration equations (i.e. equations 3 and 4), the VECMs are estimated for the different variable sets (Tables $5 \mathrm{~A}$ and $5 \mathrm{~B})$. The results indicate the short-run and long-run Granger causality tests (Granger, 1969). The optimal lag structure of one year is chosen using the AIC (Akaike, 1974). Short-run causality is determined by the statistical significance of the estimated coefficients of the first differences of variables. Long-run causality is determined by the statistical significance of the respective ECTs, using t-tests. The coefficients of the ECTs give the adjustment rate at which shortrun dynamics converge to the long-run equilibrium relationship.

The ECTs are statistically significant and negative in all cases, indicating a long-run relationship of all the pairs of the variables considered. Particularly, it comes that both business tourism spending and leisure tourism spending are statistically significant determinants of GDP and employment, and vice versa. Thus, the "feedback" or "reciprocal" hypothesis is confirmed for the Eurozone countries during the period under consideration. 
Table 5A. Panel VECM estimation results (estimations of equation 3)

\begin{tabular}{|c|c|c|c|c|}
\hline \multicolumn{2}{|c|}{ Dependent Variable } & Independent Variable & Coefficient & t-statistic \\
\hline \multirow{2}{*}{$\Delta l g d p$} & SR & $\Delta l b t s$ & 0.201 & $10.397^{* *}$ \\
\cline { 2 - 5 } & LR & ECT & -0.135 & $-5.450^{* *}$ \\
\hline \multirow{2}{*}{$\Delta l e m p l$} & SR & $\Delta l b t s$ & 0.086 & $8.520^{* *}$ \\
\cline { 2 - 5 } & LR & ECT & -0.150 & $-5.494^{* *}$ \\
\hline \multirow{2}{*}{$\Delta l r g d p$} & SR & $\Delta l l t s$ & 0.455 & $15.390^{* *}$ \\
\cline { 2 - 5 } & LR & ECT & -0.115 & $-4.920^{* *}$ \\
\hline \multirow{2}{*}{$\Delta l e m p l$} & SR & $\Delta l l t s$ & 0.165 & $10.532^{* *}$ \\
\cline { 2 - 5 } & LR & ECT & -0.190 & $-7.860^{* *}$ \\
\hline
\end{tabular}

$S R$ and $L R$ denote short-run and long-run, respectively.

** denotes statistical significance at the $5 \%$ level.

Source: Authors' elaboration

Table 5B. Panel VECM estimation results (estimations of equation 4)

\begin{tabular}{|c|c|c|c|c|}
\hline \multicolumn{2}{|c|}{ Dependent Variable } & Independent Variable & Coefficient & t-statistic \\
\hline \multirow{2}{*}{$\Delta l b t s$} & SR & $\Delta l g d p$ & 1.212 & $11.273^{* *}$ \\
\cline { 2 - 5 } & LR & ECT & -0.261 & $-6.188^{* *}$ \\
\hline \multirow{3}{*}{$\Delta l b t s$} & SR & $\Delta l e m p l$ & 1.335 & $5.891^{* *}$ \\
\cline { 2 - 5 } & LR & ECT & -0.171 & $-5.282^{* *}$ \\
\hline \multirow{2}{*}{$\Delta l l t s$} & SR & $\Delta l g d p$ & 0.776 & $14.570^{* *}$ \\
\cline { 2 - 5 } & LR & ECT & -0.181 & $-5.837^{* *}$ \\
\hline \multirow{2}{*}{$\Delta l l t s$} & SR & $\Delta l e m p l$ & 1.015 & $8.983^{* *}$ \\
\cline { 2 - 5 } & LR & ECT & -0.078 & $-3.306^{* *}$ \\
\hline
\end{tabular}

$S R$ and $L R$ denote short-run and long-run, respectively.

** denotes statistical significance at the $5 \%$ level.

Source: Authors' elaboration

\section{Conclusions}

The paper investigates the nexus of business and leisure tourism spending with GDP and employment for the Eurozone countries, during the period 2000-2018, employing sophisticated, established, panel data analysis techniques. The findings of the paper indicate that both business tourism spending and leisure tourism spending are statistically significant determinants of GDP and employment, and vice versa, thus confirming the "feedback" or "reciprocal" hypothesis. Particularly, the findings of the paper indicate a bi-directional, reciprocal, causality between business tourism spending and leisure tourism spending, on the one hand, and GDP and employment, on the other.

The findings of the paper call for a set of well-targeted and carefully-designed policy interventions focusing on promoting both business tourism and leisure tourism. This is so as tourism expansion policies may boost economic growth and higher economic growth may boost tourism expansion, in a self-sustained fashion. Tourism planners ought to demonstrate openness in new trends and challenges to meet visitors' needs and demands, whereas, at the same time, economists and entrepreneurs should embed innovation in investment plans concerning the provision of services, facilities, and infrastructure to enhance tourism expansion through memorable tourism experiences. This is, apparently, not an easy-to-achieve task, considering that exogenous economic shocks (COVID-19 is the most notable one) lead to pressures on tourism and economic activity. Overall, it remains to be seen whether and to what extent the individual economies of the Eurozone have the same capacity to reap the benefits of tourism expansion. To this end, the paper sets the basis for further empirical research. 


\section{References}

Akaike, H. (1974). A new look at the statistical model identification. IEEE Transactions on Automatic Control, 19, 716-723. DOI: 10.1109/TAC.1974.1100705

Anagnostou, A., Kallioras, D., \& Kollias, C. (2016). Governance convergence among the EU28? Social Indicators Research, 129(1), 133-146. https://doi. org/10.1007/s11205-015-1095-2

Antonakakis, N., Dragouni, M., \& Filis, G. (2015a). Tourism and growth: The times they are a-changing. Annals of Tourism Research, 50, 159-172. DOI: 10.1016/j.annals.2014.11.008

Antonakakis, N., Dragouni, M., \& Filis, G. (2015b). How strong is the linkage between tourism and economic growth in Europe? Economic Modelling, 44, 142-155. https://doi.org/10.1016/j.econmod.2014.10.018

Arellano, M., \& Bond, S.R. (1991). Some tests of specification for panel data: Monte Carlo evidence and an application to employment equations. Review of Economic Studies, 58, 277-297. https://doi. org/10.2307/2297968

Asafu-Adjaye, J. (2000). The relationship between energy consumption, energy prices and economic growth: Time series evidence from Asian developing countries. Energy Economics, 22, 615-625. https://doi.org/10.1016/S0140-9883(00)00050-5

Balaguer, J., \& Cantavella-Jorda, M. (2002). Tourism as a long-run economic growth factor: The Spanish case. Applied Economics, 34, 877 -884. https://doi. org $/ 10.1080 / 00036840110058923$

Breitung, J. (2000). The local power of some unit root tests for panel data. Advances in Econometrics, 15, 161-177. https://doi.org/10.1016/S07319053(00)15006-6

Cerdeira Bento, J.P. (2016). Tourism and economic growth in Portugal: An empirical investigation of causal links. Tourism and Management Studies, 12(1), 164-171. DOI: 10.18089/tms.2016.12117

Chao, C.-C., Hazari, B.R., Laffargue, J.-P., Sgro, P.M., \& Yu, E.S.H. (2006). Tourism, Dutch disease and welfare in an open dynamic economy. Japanese Economic Review, 57(4), 501-515. https://doi. org/10.1111/j.1468-5876.2006.00400.x

Choi, I. (2006). Unit root tests for panel data. Journal of International Money and Finance, 20, 249-272. https://doi.org/10.1016/S0261-5606(00)00048-6

Chou, M.C. (2013). Does tourism development promote economic growth in transition countries? A panel data analysis. Economic Modelling, 33: 226232. https://doi.org/10.1016/j.econmod.2013.04.024

Cortes-Jimenez, I., \& Pulina, M. (2010). Inbound tourism and long-run economic growth. Cur- rent Issues in Tourism, 13(1), 61-74. https://doi. org/10.1080/13683500802684411

Demirhan, B. (2016). Tourism-Led Growth Hypothesis in Mediterranean Countries: Evidence from a panel cointegration and Error Correction Model. Applied Economics and Finance, 3(1), 38-53. DOI: 10.11114/aef.v3i1.1207

De Vita, G., \& Kyaw, K.S. (2016). Tourism development and growth. Annals of Tourism Research, 60, 23-26. https://doi.org/10.1016/j.annals.2016.05.011

Dickey, D.A., \& Fuller, W.A. (1979). Distribution of the estimators for autoregressive time series with a unit root. Journal of the American Statistical Association, 74, 417-431. https://doi.org/10.2307/2286348

Dragouni, M., Filis, G., \& Antonakakis, N. (2013). Time-varying interdependencies of tourism and economic growth: Evidence from European countries. MPRA Papers, 48715. https://mpra.ub.unimuenchen.de/48715/

Dritsakis, N. (2004). Tourism as a long-run economic growth factor: An empirical investigation for Greece using causality analysis. Tourism Economics, 10(3), 305-316. DOI: 10.5367/0000000041895094

Dwyer, L., Forsyth, P., \& Spurr, R. (2004), Evaluating tourism's economic effects: New and old approaches. Tourism Management, 25(3) 307-317. https://doi. org/10.1016/S0261-5177(03)00131-6

Eeckels. B., Filis, G., \& Leo, C. (2012), Tourism income and economic growth in Greece: Empirical evidence from their cyclical components. Tourism Economics, 18(4), 817-834. https://doi.org/10.5367/ te. 2012.0148

Engle, R.F., \& Granger, C.W.J. (1987), Cointegration and error-correction: representation, estimation and testing. Econometrica, 55: 251-276. https://doi. org/10.2307/1913236

Engle, R.F., \& Yoo, B.S. (1987). Forecasting and testing in co-integrated systems. Journal of Econometrics, 35, 143-159. https://doi.org/10.1016/03044076(87)90085-6

Granger, C. (1964). Investigating causal relations by econometric models and cross-spectral methods. Econometrica, 37(3), 424-438. https://doi. org/10.2307/1912791

Gričar, S., Bojnec, S., Karadžić, V., \& Rakočević, S. (2016). Comparative analysis of tourism-led growth in Slovenia and Montenegro. Managing Global Transitions, 14(1), 75-92.

Holtz-Eakin, D. (1988). Testing for individual effects in autoregressive models. Journal of Econometrics, 39, 297-308. https://doi.org/10.1016/03044076(88)90060-7 
Im, K.S., Pesaran, M.H., \& Shin, Y. (2003). Testing for unit roots in heterogeneous panels. Journal of Econometrics, 115, 53-74. https://doi.org/10.1016/ S0304-4076(03)00092-7

Ivanov, S., \& Webster, C. (2007). Measuring the impact of tourism on economic growth. Tourism Economics, Vol. 13, No. 3, pp. 379-388. https://doi. org $/ 10.5367 / 000000007781497773$

Johansen, S. (1988). Statistical analysis of cointegration vectors, Journal of Economics Dynamic and Control, 12, 231-254. https://doi.org/10.1016/01651889(88)90041-3

Kallioras, D., Gkotinakou, G., \& Fardas, M. (2017). Detecting trends of convergence among the Eurozone countries in terms of economic freedom. International Journal of Economics and Finance Studies, 9(1), 33-47.

Kallioras, D., Topaloglou, L., \& Venieris, S. (2009). Tracing the determinants of economic cross-border interaction in the European Union. Spatium, 21, 1-10. DOI: 10.2298/SPAT0921001K

Kasimati, E. (2011). Economic impact of tourism on Greece's economy: Cointegration and causality analysis. International Research Journal of Finance and Economics, 79, 79-85.

Katırcıoğlu, S.T. (2009a). Tourism, trade and growth: The case of Cyprus. Applied Economics, 41(21), 27412750. https://doi.org/10.1080/00036840701335512

Katırcioğlu, S.T. (2009b). Testing the tourismled growth hypothesis: The case of Malta. Acta Oeconomica, 59(3), 331-343. DOI: 10.1556/AOecon.59.2009.3.4

Khan, H., Phang, S., \& Toh, R. (1995). The multiplier effect: Singapore's hospitality industry. Cornell Hotel and Restaurant Administration Quarterly, 36, 64-69. https://doi.org/10.1177/001088049503600121

Lee, C.C., \& Chang, C. (2008). Tourism development and economic growth: A closer look at panels. Tourism Management, 29, 180-192. https://doi. org/10.1016/j.tourman.2007.02.013

Levin, A., Lin, C.F., \& Chu, C. (2002). Unit root tests in panel data: asymptotic and finite sample properties. Journal of Econometrics, 108, 1-24. https://doi. org/10.1016/S0304-4076(01)00098-7

Lim, J., \& Won, D. (2020). How Las Vegas' tourism could survive an economic crisis? Cities, 100, 102643. https://doi.org/10.1016/j.cities.2020.102643

Maddala, G.S., \& Wu, S. (1999). A comparative study of unit root tests with panel data and a new simple test. Oxford Bulletin of Economics and Statistics, 61(S1), 631-652. https://doi.org/10.1111/14680084.0610s1631

Mark, N.C., \& Sul, D. (2003). Cointegration vector estimation by panel DOLS and long-run money demand. Oxford Bulletin of Economics and
Statistics, 65(5), 655-680. https://doi.org/10.1111/ j.1468-0084.2003.00066.x

Massidda, C., \& Mattana, P. (2013). A SVECM analysis of the relationship between international tourism arrivals, GDP and trade in Italy. Journal of Travel Research, 52(1), 93-105. https://doi. org/10.1177/0047287512457262

Neves, D.C., Fernandes, A.J, \& Pereira, E.T. (2015). Determinants of touristic attraction in Portuguese regions and their impact on GDP. Tourism Economics, 21(3), 629-648. DOI: 10.5367/te.2013.0361

Nowak, J.J. (2007). Tourism capital, good imports and economic growth: Theory and evidence for Spain. Tourism Economics, 13(4), 515-536. https://doi. org $/ 10.5367 / 000000007782696113$

Oh, C.O. (2005). The contribution of tourism development to economic growth in the Korean economy. Tourism Management, 26(1), 39-44. https://doi. org/10.1016/j.tourman.2003.09.014

Oh, W., \& Lee, K. (2004a). Causal relationship between energy consumption and GDP revisited: The case of Korea 1970-1999. Energy Economics, 26(1), 51-59. https://doi.org/10.1016/S0140-9883(03)00030-6

Oh, W., \& Lee, K. (2004b). Energy consumption and economic growth in Korea: Testing the causality relation. Journal of Policy Modeling, 26, 973-981. https://doi.org/10.1016/j.jpolmod.2004.06.003

Pablo-Romero, M.P., \& Molina, J.A. (2013). Tourism and economic growth: A review of empirical literature. Tourism Management Perspectives, 8, 28-41. https://doi.org/10.1016/j.tmp.2013.05.006

Petrakos, G., Kallioras, D., \& Anagnostou, A. (2011). Regional convergence and growth in Europe: Understanding pattens and determinants. European Urban and Regional Studies, 18(4), 375-391. https:// doi.org/10.1177/0969776411407809

Škrinjarić, T. (2019). Examining the causal relationship between tourism and economic growth: Spillover Index approach for selected CEE and SEE countries. Economies, 7(1), 19. https://doi.org/10.3390/ economies7010019

Soukiazis, E., \& Proença, S. (2008). Tourism as an alternative source of regional growth in Portugal: A panel data analysis at NUTS II and III levels. Portuguese Economic Journal, 7, 43-61. DOI: 10.1007/ s10258-007-0022-0

Tsui, K., Hasan, M., Tan, D., Lau, O., \& Balli, F. (2017). New Zealand business tourism: Exploring the impact of economic policy uncertainties. Tourism Economics, 24, 386-417. https://doi. org/10.1177/1354816617731387

Tugcu, C.T. (2014). Tourism and economic growth nexus revisited: A panel causality analysis for the case of the Mediterranean region. Tourism Man- 
The Nexus of Tourism Spending with Economic Performance:

A Panel Data Analysis for the Eurozone Area

agement, 42, 207-212. https://doi.org/10.1016/j.tourman.2013.12.007

Wald, A. (1945). Sequential tests of statistical hypotheses. Annals of Mathematics, 16(2), 117-186. doi: 10.1214/aoms/1177731118
World Tourism Travel Council (2019). Travel and tourism economic impact 2019 world, World Travel \& Tourism Council (WTTC), London. 